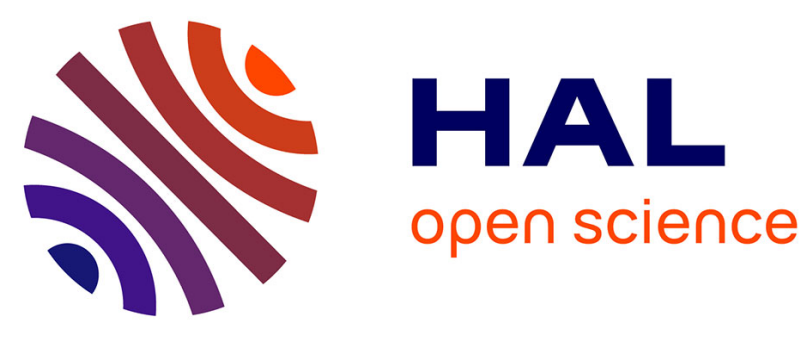

\title{
The LONSCAPE instrument, a Light Optical Nephelometer Sizer and Counter for Aerosols in Planetary Environments
}

Jean-Baptiste Renard, Olivier Mousis, Gwenaël Berthet, Jean-Michel Geffrin, Anny Chantal Levasseur-Regourd, Pascal Rannou, Nicolas Verdier

\section{To cite this version:}

Jean-Baptiste Renard, Olivier Mousis, Gwenaël Berthet, Jean-Michel Geffrin, Anny Chantal Levasseur-Regourd, et al.. The LONSCAPE instrument, a Light Optical Nephelometer Sizer and Counter for Aerosols in Planetary Environments. EGU General Assembly 2020, May 2020, Vienne, Austria. 10.5194/egusphere-egu2020-3495 . insu-02610591

\section{HAL Id: insu-02610591 \\ https://hal-insu.archives-ouvertes.fr/insu-02610591}

Submitted on 7 Feb 2022

HAL is a multi-disciplinary open access archive for the deposit and dissemination of scientific research documents, whether they are published or not. The documents may come from teaching and research institutions in France or abroad, or from public or private research centers.
L'archive ouverte pluridisciplinaire HAL, est destinée au dépôt et à la diffusion de documents scientifiques de niveau recherche, publiés ou non, émanant des établissements d'enseignement et de recherche français ou étrangers, des laboratoires publics ou privés.

\section{(c)(1)}

Distributed under a Creative Commons Attribution| 4.0 International License 
EGU2020-3495

https://doi.org/10.5194/egusphere-egu2020-3495

EGU General Assembly 2020

(c) Author(s) 2022. This work is distributed under

the Creative Commons Attribution 4.0 License.

\title{
The LONSCAPE instrument, a Light Optical Nephelometer Sizer and Counter for Aerosols in Planetary Environments
}

\author{
Jean-Baptiste Renard ${ }^{1}$, Olivier Mousis ${ }^{2}$, Gwenaël Berthet ${ }^{1}$, Jean-Michel Geffrin ${ }^{3}$, Anny-Chantal \\ Levasseur-Regourd ${ }^{4}$, Pascal Rannou ${ }^{5}$, and Nicolas Verdier ${ }^{6}$ \\ 'LPC2E-CNRS, Orléans cedex 2, France (jbrenard@cnrs-orleans.fr) \\ ${ }^{2}$ LAM, Marseille, France \\ ${ }^{3}$ Institut Fresnel, Marseille, France \\ ${ }^{4}$ LATMOS / Sorbonne Université, Paris, France \\ ${ }^{5}$ GSMA, Reims, France \\ ${ }^{6}$ CNES, Toulouse, France
}

Liquid and solid particles are present in the atmosphere of many Solar System objects. Measuring aerosol properties can provide major constraints about both atmospheric composition and dynamics. While some bulk aerosol properties can be estimated using remote measurements, the size distributions and the typologies of the aerosols, which are related to their formation process, their origin and their evolution, are often poorly known. We propose a new concept of optical instrument dedicated to in situ measurements of aerosols as part of the science payload of an atmospheric entry probe or of a surface module. It relies the Earth atmospheric light aerosol counter LOAC used since 2013 under various types of balloons. This instrument measures the aerosol concentrations in 19 size classes between 0.2 and 50 micrometers, and estimates their typology

The LONSCAPE (Light Optical Nephelometer Counter Sizer and Counter for Aerosols in Planetary Environments) concept combines counter measurements and nephelometric measurements at several phase angles, particle by particle, to retrieve for all size classes the concentrations and the scattering functions. This approach is the novelty of the instrument concept. The scattering functions can be compared to results of theoretical calculations but also to laboratory databases obtained for levitating particles and from the microwave analogy technics, to retrieve the refractive indices of the liquid and solid particles to better identify their nature and origin. Up to 10 angles measurements for the scattering function and one angle measurement for the counting provide an optimal configuration to distinguish between liquid, icy and possibly solid particles in the Uranus or Neptune atmosphere. Such an instrument must be able to detect up to tens of particles greater than 0.1 micrometer within $1 \mathrm{~cm}^{3}$.

For ice giants, the instrument must work for pressures up to 10 bars. No pumping system should be needed since the aerosols will be injected in the optical chamber by an inlet parallel to the descent motion of the probe under parachutes. Considering the relative velocity between the 
atmosphere and the probe, the electronics must be able to detect particles crossing the laser beam up to several tens of $\mathrm{m} / \mathrm{s}$, which can be done by "conventional" electronics. Preliminary studies show that the instrument could have a total mass of about $2 \mathrm{~kg}$ and an electric consumption of about $2 \mathrm{~W}$. 